Terbit online pada laman web jurnal : http://jurnal.iaii.or.id

DURNAI, R ISTI
(Rekayasa Sistem dan Teknologi Informasi)
Vol.2 No.2(2018) $542-553 \quad$ ISSN : 2580-0760 (media online)

\title{
Pengembangan Digital Library Universitas Bina Darma Menggunakan Pendekatan Human Computer Interaction
}

\author{
Kurniati \\ ${ }^{a}$ Teknik Informatika, Ilmu Komputer, Universitas Bina Darma Palembang, kurniati@binadarma.ac.id
}

\begin{abstract}
Bina Darma University has implemented a digital library which is located in http://digilib.binadarma.ac.id. With this facility, it will be easier for students, faculty, and visitors to obtain information relating to digital documents such as journals, theses or other library activities. However, application of digital library Bina Darma University in Palembang assessed not maximized because of the small number of visitors who use these facilities and prefer to search digital documents such as journals by search engines as a source of information. Human Computer Interaction (HCI) approach method can be used to create a system and within their right to the user. In addition, to facilitate the development, paper prototype method helps in the design of a more complete according to user needs. So, will result in generating a new design that can increase the interest of visitors to access digital library Universitas Bina Darma Palembang as the main alternative in the search for information and as a self-development.
\end{abstract}

Keywords: digital library, Human Computer Interaction (HCI), prototype, usability

\begin{abstract}
Abstrak
Universitas Bina Darma telah menerapkan digital library yang beralamat di http://digilib.binadarma.ac.id.Dengan adanya fasilitas ini, akan mempermudah mahasiswa, dosen, dan pengunjung mendapatkan informasi berkenaan dengan dokumen digital seperti jurnal, skripsi ataupun aktivitas perpustakaan lainnya. Namun, penerapan digital library Universitas Bina Darma Palembang dinilai belum maksimal karena masih sedikitnya pengunjung yang memanfaatkan fasilitas tersebut dan lebih memilih melakukan pencarian dokumen elektronik seperti jurnal dengan search engines sebagai sumber informasi. Metode usability yang merupakan salah satu dari pendekatan Human Computer Interaction (HCI) dapat digunakan untuk mengukur kepuasan pengguna terhadap sistem.Dengan menggunakan pendekatan Human Computer Interaction (HCI) kita dapat mengukur kepuasan pengguna dengan melakukan pengukuran terhadap lima indikator yaitu learnability, efficiency, memorability, error dan satisfaction. Sehingga, akan menghasilkan suatu sistem yang user friendly dan tepat sesui dengan keinginan pengguna. Selain itu, untuk mempermudah dalam pengembangan, metode prototype membantu dalam desain secara lebih lengkap sesuai kebutuhan pengguna. Sehingga, akan menghasilkan desain baru yang mampu meningkatkan minat pengunjung untuk mengakses digital library Universitas Bina Darma Palembang sebagai alternatif utama dalam pencarian informasi dan sebagai tempat pengembangan diri mahasiswa Universitas Bina Darma dalam melakukan penelitian.
\end{abstract}

Kata kunci: digital library, Human Computer Interaction (HCI), prototype, usability

(C) 2018Jurnal RESTI

\section{Pendahuluan}

Interaksi manusia dan komputer atau human computer interaction (HCI) merupakan sebuah disiplin ilmu yang mempelajari perancangan, implementasi dan evaluasi sistem komputasi interaktif dan berbagai aspek terkait. [1]Dengan memperhatikan pengguna maka dapat diciptakan suatu sistem yang sesuai dan tepat bagi pengguna serta dapat memberikan kenyamanan kepada pengguna di dalam menggunakan sistem.Digital library berfungsi sebagai tempat pencarian informasi dan sebagai sarana penunjang belajar bagi civitas akademika Universitas Bina Darma. Namun, pada saat ini kepuasan pengguna terhadap sistem masih belum terpenuhi. Secara keseluruhan dari tampilan digital libraryUniversitas Bina Darma, masih belum berfungsi maksimal karena masih sedikit sekali user seperti mahasiswa, dosen dan karyawan Universitas Bina Darma yang memanfaatkan fasilitas tersebut dan lebih memilih melakukan pencarian dokumen digital menggunakan search engines sebagai sumber informasi

Diterima Redaksi : 22-05-2018 | Selesai Revisi : 14-07-2018 | Diterbitkan Online : 15-07-2018 
dibandingkan berkunjung langsung ke perpustakaan atau mengakses digitallibrary.

Hal itu dikarenakan pada saat pengguna melakukan pencarian informasi,penggunamengalami kesulitan dalam menemukan informasi yang dibutuhkan Secara umum metode penelitian diartikan sebagai cara tersebut dikarenakan pada saat memasukan key word ilmiah untuk mendapatkan data dengan tujuan dan pada menu pencarian menu tersebut tidak dapat kegunaan tertentu. Dalam penelitian ini, metode berfungsi. Selain itu, fileyang ada pada digilib tersebut penelitian yang digunakan dengan menggunakan tidak dapat di download oleh pengguna. Berdasarkan metode penelitian kuantitatif. [5]Metode kuantitatif permasalan tersebut perlu dilakukannya pengembangan menekankan fenomena-fenomena objektif dan dikaji terhadap sistemguna meningkatkan fungsional sistem. secara kuantitatif. Maksimalisasi objektivitas desain Pendekatan human computer interactiondapat penelitian ini dilakukan dengan menggunakan angkadigunakan untuk melakukanpengujian terhadap angka, pengolahan statistik, struktur dan percobaan usability sistem terhadap penilaian kepuasan terkontrol. [6]

penggunaterhadap sistem. Sehingga, akan mempermudah dalam melakukan pengembangan dalam menghasilkan sebuah sistem yang jauh lebih baik daripada sebelumnya.

Menurut Jacob Nealsen dalam Prihati, model analisis dengan menerapkan konsep human computer interaction menggunakan lima kriteria yaitu learnability, efficiency, memorability, errors dan satisfactionuntuk mengukur usability pada sistem yang dikembangangkan. Kriteria Nealsen ini dipilih karena kelima kriteria tersebut dapat menjadi tolak ukur untuk mengetahui tingkat kepuasan pengguna pada suatu sistem dengan melakukan pengukuran usability. Sehingga, dari pengukuran tinggi rendahnya usability suatu sistem mengindikasikan seberapa besar konsep human computer interactionyang sudah diterapkan dalam sistem tersebut. [2]

\section{Tinjauan Pustaka}

\subsection{Perpustakaan Digital (Digital Library)}

Perpustakaan digital adalah perpustakaan yang koleksinya berupa koleksi digital, perpustakaan digital biasanya berbasis pada jaringan global bahkan banyak yang melalui internet. Sehingga, sistem tersebut dapat di akses oleh banyak pengguna dari tempat yang tak terhingga jaraknya. Koleksi digital hanya bisa diakses dan dibaca dengan menggunakan komputer atau peralatan membaca lain yang dapat membaca data digital.[3]

\subsection{Human Computer Interaction}

HumanComputerInteraction (HCI) merupakan disiplin ilmu yang mempelajari bagaimana manusia berinteraksi dengan komputer termasuk tugas-tugas yang menjadi pengikat diantara keduanya. Pembelajaran interaksi manusia dan komputer akan Prototyping merupakan teknik pengembangan yang menilai suatu piranti lunak pembelajar dari menggunakan prototypeuntuk menggambarkan sistem, beberapafaktor berikut diantaranya pertama adalah user sehingga pengguna atau pemilik sistem mempunyai friendlyyang berarti sistem tersebut dirancang untuk gambaran pengembangansistem yang akan kemudahan pengguna. Sedangkan yang kedua adalah dilakukannya. [12] Model prototype cocok digunakan error freeyang maksudnya adalah meskipun mungkin untuk menggali spesifikasi kebutuhan pelanggan secara lebih detail. 


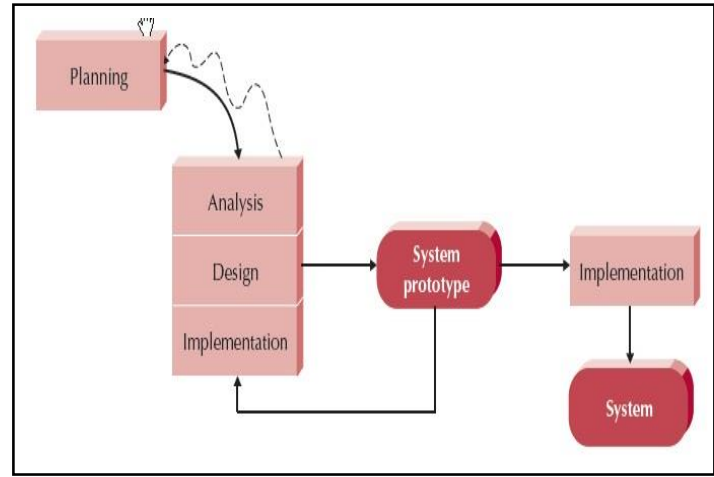

Sumber : Rosa A.S, M.Shalahuddin, 2014, Rekayasa Perangkat Lunak

Gambar 1. Prototype Paradigma

\section{Hasil dan Pembahasan}

Hasil dari analisis sistem terhadap kepuasan pengguna pada tampilan digital libraryUniversitas Bina Darma, masih belum berfungsi maksimal karena masih sedikit sekali user seperti mahasiswa, dosen dan karyawan Universitas Bina Darma yang memanfaatkan fasilitas tersebut dan lebih memilih melakukan pencarian dokumen digital menggunakan search engines sebagai sumber informasi dibandingkan berkunjung langsung ke perpustakaan atau mengakses digitallibrary.

Dengan penyebaran kuesioner yang dilakukan oleh peneliti terhadap seratus dua puluh responden, memperkuat alasan kenapa fasilitas ini tidak berjalan maksimal pada civitas akademika Universitas Bina Darma.

\subsection{Selecting a Representetif Sample and Recruiting Participant}

Peneliti melakukan penyebaran kuesioner terhadap seratus dua puluh responden untuk mewakili keseluruhan pengguna dari golongan dosen, karyawan dan mahasiswa yang ada di Universitas Bina Darma.

Penyebaran kuesioner ini dilakukan melalui aplikasi google drive berdasarkan anggota dari salah satu akun media sosialnya yaitu facebook.com, untuk mengetahui tingkat kepuasan pengguna terhadap digital library Universitas Bina Darma. Sehingga, dari jumlah tersebut akan dikelompokkan sesuai dengan tingkatan pengguna yaitu kategori aktif, terampil dan awam.

Setelah itu, lima responden akan diambil sebagai sample untuk melakukan usability test yang merupakan salah satu bagian dari Human Computer Interaction terhadap penerapan digital library Universitas Bina Darma pada situs website http://digilib.binadarma.ac.id, seperti di Tabel 1.

\subsection{Conducting the Usability Test}

Berdasarkan hasil rekaptulasi jawaban responden yang melakukan uji ketergunaan (usability test), maka selanjutnya akan dilakukan proses menentukan waktu yang dibutuhkan responden dalam mengerjakan tugas yang diberikan dalam skrip. Dimana dari data di atas tercatat seperti tercantum dalam tabel 2.

\begin{tabular}{|c|c|c|c|c|c|}
\hline $\begin{array}{l}\text { kode } \\
\text { respon } \\
\text { den }\end{array}$ & $\begin{array}{l}\text { nama } \\
\text { respon } \\
\text { den }\end{array}$ & umur & status & $\begin{array}{l}\mathrm{j} \\
\mathrm{k}\end{array}$ & kategori \\
\hline R1 & R1 & $>20$ & karyawan & $\mathrm{p}$ & aktif \\
\hline $\mathrm{R} 2$ & R59 & $>20$ & karyawan & 1 & aktif \\
\hline R3 & R102 & $>20$ & karyawan & 1 & terampil \\
\hline $\mathrm{R} 4$ & R16 & $>20$ & mahasiswa & 1 & terampil \\
\hline R5 & R119 & $>20$ & mahasiswa & 1 & awam \\
\hline
\end{tabular}

Tabel 2. Waktu Pengujian

\begin{tabular}{ccccc}
\hline No & $\begin{array}{c}\text { Kode } \\
\text { responden }\end{array}$ & $\begin{array}{c}\text { Kuesion } \\
\text { er 1 }\end{array}$ & $\begin{array}{c}\text { Kuesio } \\
\text { ner 2 }\end{array}$ & $\begin{array}{c}\text { Total waktu } \\
\text { (menit) }\end{array}$ \\
\hline 1 & R1 & 7 & 5 & 12 \\
2 & R59 & 6 & 5 & 11 \\
3 & R102 & 8 & 5 & 13 \\
4 & R16 & 7 & 5 & 12 \\
5 & R119 & 8 & 5 & 13 \\
Rata-rata & & & 12.2 \\
\hline
\end{tabular}

Setelah melihat data di atas barulah dapat membuat kesimpulan, bahwasanya rata-rata waktu yang dibutuhkan adalah 12,2 menit. Yang mana nilai waktu tersebut sesui dengan yang diungkapkan oleh Krug S (2006:152), bahwa untuk pengujian membutuhkan waktu sekitar satu jam"first usable version".

\subsection{Debriefing The Participant}

Pada tahapan ini disediakan responden seperti Tabel 3.

Tabel 3. Daftar Pertanyaan Kuesioner

\begin{tabular}{|c|c|c|}
\hline Variabel & Indikator & Pernyataan \\
\hline \multirow[t]{5}{*}{$\begin{array}{l}\text { Kualitas } \\
\text { Layanan } \\
\left(\mathrm{X}_{1}\right)\end{array}$} & $\begin{array}{l}\text { Learnab } \\
\text { ility }\end{array}$ & $\begin{array}{l}\text { 1. Digital library Universitas } \\
\text { Bina Darma telah berjalan } \\
\text { sesuai dengan fungsi yang } \\
\text { saya harapkan. }\end{array}$ \\
\hline & & $\begin{array}{l}\text { 2. Digital library Universitas } \\
\text { Bina Darma dapat } \\
\text { dipelajari dengan cepat }\end{array}$ \\
\hline & & 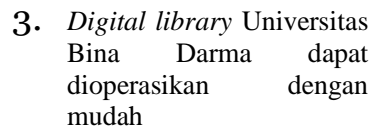 \\
\hline & & $\begin{array}{l}\text { 4. Digital library Universitas } \\
\text { Bina Darma memiliki } \\
\text { menu yang mudah diingat } \\
\text { dan dipelajari. }\end{array}$ \\
\hline & & $\begin{array}{l}\text { 5. Digital library Universitas } \\
\text { Bina Darma dapat diakses } \\
\text { dimana saja. }\end{array}$ \\
\hline
\end{tabular}




\begin{tabular}{|c|c|c|}
\hline \multirow[t]{6}{*}{ Efficiency } & 1. & $\begin{array}{l}\text { Pencarian Alamat Digital } \\
\text { library Universitas Bina } \\
\text { Darma dapat dioperasikan } \\
\text { dengan mudah }\end{array}$ \\
\hline & \multirow[t]{2}{*}{2.} & $\begin{array}{l}\text { Proses input data } \\
\text { menggunakan }\end{array}$ \\
\hline & & $\begin{array}{l}\text { library Universitas Bina } \\
\text { Darma lebih mudah dan } \\
\text { cepat }\end{array}$ \\
\hline & 3. & $\begin{array}{l}\text { Semua fitur yang disediakan } \\
\text { Digital library Universita } \\
\text { Bina Darma dapat berjalar } \\
\text { dengan baik }\end{array}$ \\
\hline & 4. & \begin{tabular}{lrr} 
Aplikasi & yang & terdapa \\
didalam & Digital & librar \\
Universitas & Bina & Darm \\
dapat & \multicolumn{2}{c}{ melengkap }
\end{tabular} \\
\hline & 5. & $\begin{array}{l}\text { Digital library Universita } \\
\text { Bina Darma dapa } \\
\text { menampung banyak tuga } \\
\text { yang akan dikerjakan olel }\end{array}$ \\
\hline \multirow[t]{5}{*}{$\begin{array}{l}\text { Memoriabilit } \\
y\end{array}$} & 1. & $\begin{array}{lrr}\text { Tampilan Digital } & \text { library } \\
\text { Universitas Bina } & \text { Darma } \\
\text { mudah dingat } & \text { oleh } \\
\text { pengguna } & & \end{array}$ \\
\hline & 2. & $\begin{array}{l}\text { Digital library Universitas } \\
\text { Bina Darma ini } \\
\text { dioperasikan } \\
\text { pengguna }\end{array}$ \\
\hline & 3. & $\begin{array}{l}\text { Alamat Digital library } \\
\text { Universitas Bina } \\
\text { mudah di ingat oleh } \\
\text { pengguna }\end{array}$ \\
\hline & 4. & $\begin{array}{l}\text { Menu / Link Digital } \\
\text { library Universitas Bina } \\
\text { Darma mudah diingat } \\
\text { oleh pengguna }\end{array}$ \\
\hline & 5. & $\begin{array}{l}\text { Digital library Universitas } \\
\text { Bina Darma dapat } \\
\text { digunakan kapan saja oleh } \\
\text { pengguna }\end{array}$ \\
\hline \multirow[t]{5}{*}{ Error } & 1. & \multirow{5}{*}{$\begin{array}{l}\text { Digital library } \\
\text { Universitas Bina Darma } \\
\text { dapat di akses tanpa error } \\
\text { Link - link yang ada } \\
\text { dapat berfungsi maksimal } \\
\text { Search engine Digital } \\
\text { library Universitas Bina } \\
\text { Darma dalam mencari } \\
\text { data berfungsi dengan } \\
\text { maksimal sesui harapan } \\
\text { saya melakukan } \\
\text { Dalam pencarian informasi dapat } \\
\text { ditemukan dengan cepat } \\
\text { Mudah dalam pencarian } \\
\text { informasi saat kita } \\
\text { memilih menu yang ada }\end{array}$} \\
\hline & 2. & \\
\hline & 3. & \\
\hline & 4. & \\
\hline & 5. & \\
\hline
\end{tabular}

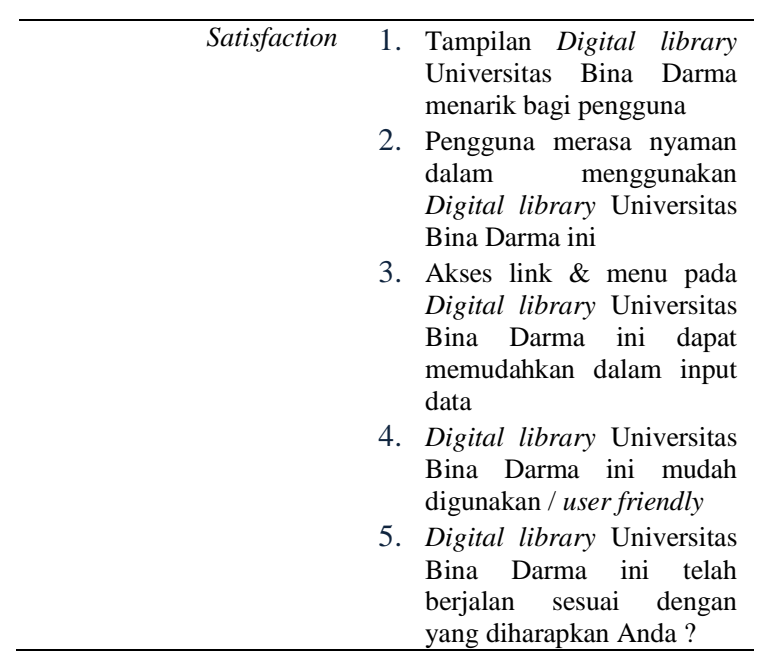

\subsection{Analyzing The Data Of Usability Test}

Pada tahap ini, penelitian akan dilanjutkan dengan melakukan beberapa tahapan dalam menentukan hasil uji kuesioner, yaitu: menentukan waktu pengujian, melakukan perhitungan persentase jawaban responden, melalui prilaku rasponden, dan terakhir melakukan perhitungan bobot prilaku responden.

\subsubsection{Melakukan Perhitungan Persentase Jawaban Responden}

Pada tahap proses ini setiap jawaban responden akan di nilai dalam bentuk angka dengan ketentuan nilai 1 (satu) jika ditemukan, dan nialai 0 (nol) jika tidak ditemukan. Hal ini dilihat dari ada tidaknya pertanyaan responden yang tidak tidak terisi atau tidak memiliki jawaban. Dari setiap poin tugas akan dihitung berapa jumlah yang ditemukan dan berapa jumlah yang tidak ditemukan.

Pada masing-masing aspek usability akan dihitung baik yang terjawab oleh responden maupun yang tidak. Secara keseluruhan dari lima orang sampel menunjukan pertanyaan responden yang ditemukan sebesar $0.8 \%$ dan yang tidak ditemukan sebesar 99.2\%. Jadi dapat disimpulkan bahwa hampir semua pertanyaan yang diberikan kepada responden terisi.

\subsubsection{Menilai Prilaku Responden}

Pada tahap proses ini, dicoba melakukan penilaian terhadap prilaku responden dengan beberapa symbol atas pertanyaan seperti untuk jawaban A artinya antusias, untuk jawaban B artinya biasa saja, jawaban R artinya ragu-ragu, jawaban $\mathrm{K}$ artinya terlihat khawatir, jawaban S artinya salah memahami, dan jawaban $\mathrm{M}$ artinya menyerah.

\subsubsection{Perhitungan Bobot Perilaku Responden}

Pada tahapan ini, dari tabel di atas diperoleh rata-rata dari prilaku yang dilkukan oleh setiap responden dengan melakukan perubahan terhadap nilai prilaku ke dalam bentuk angka dengan mengikuti aturan sebagai 
berikut untuk huruf B akan diganti nilai 4, untuk huruf Darma adalah jawaban pengguna banyak menyatakan Rakan dinilai dengan nilai 3, untuk huruf K akan dinilai setuju berarti penerapan sistem ini sudah dinilai baik. dengan nilai 2, untuk huruf $\mathrm{S}$ akan dinilai dengan nilai 1 dan huruf $\mathrm{M}$ akan dinilai dengan nilai 0 .

\subsubsection{Rekaputalasi Pengukuran Usability}

Tahapan ini merupakan proses pengelompokan data berdasarkan usability test yang telah dilakukan sebelumnya dari lima komponen usability yaitu learnability, efficiency, memorability, error dan satisfaction.

Tabel 4. Skala Pengukuran Learnibility

\begin{tabular}{ccccccc}
\hline $\begin{array}{c}\text { Responde } \\
\mathrm{n}\end{array}$ & $\mathrm{SS}$ & $\mathrm{S}$ & $\mathrm{KS}$ & $\mathrm{TS}$ & $\mathrm{STS}$ & Total \\
\hline 1 & 0 & 4 & 12 & 0 & 0 & 16 \\
2 & 5 & 16 & 0 & 0 & 0 & 21 \\
3 & 5 & 16 & 0 & 0 & 0 & 21 \\
4 & 0 & 8 & 9 & 0 & 0 & 17 \\
5 & 0 & 0 & 15 & 0 & 0 & 15 \\
Total & 10 & 44 & 36 & 0 & 0 & 90 \\
\hline
\end{tabular}

Dari tabel 4, didapat kesimpulan bahwa pengukuran usability pada learnability digital library Universitas Bina Darma adalah jawaban pengguna banyak menyatakan setuju berarti penerapan sistem ini sudah dinilai baik.

Tabel 5. Skala Pengukuran Efficiency

\begin{tabular}{ccccccc}
\hline $\begin{array}{c}\text { Responde } \\
\text { n }\end{array}$ & SS & S & KS & TS & STS & Total \\
\hline 1 & 0 & 12 & 6 & 0 & 0 & 18 \\
2 & 0 & 4 & 9 & 2 & 0 & 15 \\
3 & 5 & 16 & 0 & 0 & 0 & 21 \\
4 & 0 & 8 & 9 & 0 & 0 & 17 \\
5 & 0 & 20 & 0 & 0 & 0 & 20 \\
Total & 5 & 60 & 24 & 2 & 0 & 91 \\
\hline
\end{tabular}

Dari tabel 5, didapat kesimpulan bahwa pengukuran usability pada efficiency digital library Universitas Bina Darma adalah jawaban pengguna banyak menyatakan setuju berarti penerapan sistem ini sudah dinilai baik.

Tabel 6. Skala Pengukuran Memorability

\begin{tabular}{ccccccc}
\hline \multirow{2}{*}{ Responden } & SS & S & KS & TS & STS & Total \\
& & & & & & \\
\hline 1 & 0 & 8 & 9 & 0 & 0 & 17 \\
2 & 0 & 16 & 3 & 0 & 0 & 19 \\
3 & 5 & 12 & 0 & 0 & 0 & 17 \\
4 & 0 & 4 & 12 & 0 & 0 & 16 \\
5 & 0 & 12 & 6 & 0 & 0 & 18 \\
Total & 5 & 52 & 30 & 0 & 0 & 87 \\
\hline
\end{tabular}

Dari tabel 6, didapat kesimpulan bahwa pengukuran usability pada memorability digital library Universitas Bina Darma adalah jawaban pengguna banyak menyatakan setuju berarti penerapan sistem ini sudah dinilai baik.

Dari tabel 7, didapat kesimpulan bahwa pengukuran usability pada error digital library Universitas Bina

Tabel 7. Skala Pengukuran Error

\begin{tabular}{ccccccc}
\hline Responden & SS & S & KS & TS & STS & Total \\
\hline 1 & 0 & 16 & 3 & 0 & 0 & 19 \\
2 & 0 & 0 & 9 & 2 & 1 & 12 \\
3 & 5 & 16 & 0 & 0 & 0 & 21 \\
4 & 0 & 0 & 15 & 0 & 0 & 15 \\
5 & 0 & 8 & 9 & 0 & 0 & 17 \\
Total & 5 & 40 & 36 & 2 & 1 & 84 \\
\hline
\end{tabular}

Tabel 8. Skala Pengukuran Satisfaction

\begin{tabular}{ccccccc}
\hline Responde & SS & S & KS & TS & STS & Total \\
\hline 1 & 0 & 20 & 0 & 0 & 0 & 20 \\
2 & 0 & 12 & 6 & 0 & 0 & 18 \\
3 & 0 & 16 & 0 & 0 & 1 & 17 \\
4 & 0 & 0 & 15 & 0 & 0 & 15 \\
5 & 0 & 20 & 0 & 0 & 0 & 20 \\
Total & 0 & 68 & 21 & 0 & 1 & 90 \\
\hline
\end{tabular}

Dari tabel 8, didapat kesimpulan bahwa pengukuran usability pada satisfaction digital library Universitas Bina Darma adalah jawaban pengguna banyak menyatakan setuju berarti penerapan sistem ini sudah dinilai baik.

Tabel 9. Rekapitulasi Hasil Pengukuran

\begin{tabular}{ccccccc}
\hline $\begin{array}{c}\text { Skala } \\
\begin{array}{c}\text { Pengukur } \\
\text { an }\end{array}\end{array}$ & L & E & S & M & Er & $\begin{array}{c}\text { Total } \\
\text { Nilai }\end{array}$ \\
\hline SS & 10 & 5 & 5 & 5 & 0 & 25 \\
S & 44 & 60 & 52 & 40 & 68 & 264 \\
KS & 36 & 24 & 3 & 36 & 21 & 147 \\
& & & 0 & & & \\
TS & 0 & 2 & 0 & 2 & 0 & 4 \\
STS & 0 & 0 & 0 & 1 & 1 & 2 \\
\hline
\end{tabular}

Keterangan : $\mathrm{L}=$ Learnibility, $\mathrm{E}=$ Efficiency, $\mathrm{S}=$ Satisfaction, $\mathrm{M}=$ Memorability dan $\mathrm{Er}=$ Error

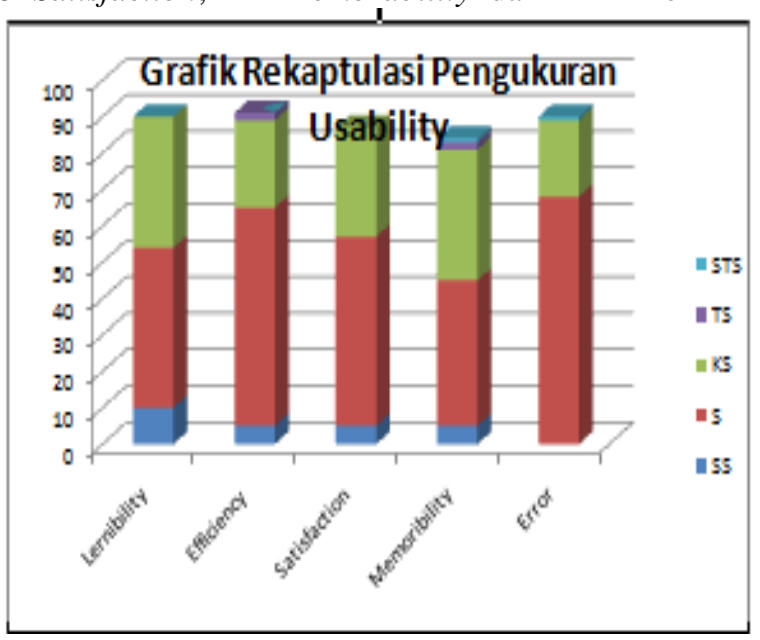

Gambar 2 Grafik Rekapitulasi 
Dari tabel dan grafik di atas menunjukkan bahwa Mengacu pada fungsi hasil integrasi sistem digital secara keseluruhan digital library Universitas Bina library dan library management sistem maka dapat Darma sudah baik karena dari dua puluh lima dibuat beberapa use case antara lain : mencari koleksi, pertanyaan yang berhubungan dengan penerapan membaca koleksi, men-download koleksi, digital library selama ini responden menjawab setuju merekomendasikan koleksi, mengubah password, dengan bobot nilai mencapai 264.

\subsection{Pengembangan Sistem}

melihat status koleksi, menambah koleksi, membuat laporan, mengelola pinjaman koleksi, meng-upload koleksi, mengelola data anggota, mengelola data Sesuai dengan tahapan yang telah dijabarkan pustakawan, mengelola data SysAdmin dan mengelola sebelumnya bahwa digunakan metode pengembangan migrasi data.

sistem prototype. Dimana dalam metode ini terdapat beberapa tahapan kerja yang dilakukan, yaitu :

\subsubsection{Tahap Analisis}

Pada tahap ini dilakukan identifikasi masalah dan pencarian solusi untuk mengatasi permasalahan. Dari hasil yang didapat saat melakukan analisis pada sistem digital library Universitas Bina Darma menggunakan pendekatan human computer interaction. Cara yang diambil yaitu dengan melakukan usability test pada 120 responden dan memilih lima diantaranya sebagai sampel, maka dapat disimpulkan bahwa secara keseluruhan sistem sudah baik. Namun, pada menu pencarian user mengalami kesulitan dalam memperoleh informasi terutama pada pencarian metadata. Pada saat user akan melakukan pencarian metadata, hasil tidak ditemukan dan user harus mencarinya secara manual, seperti yang ditunjukan pada gambar 3 .

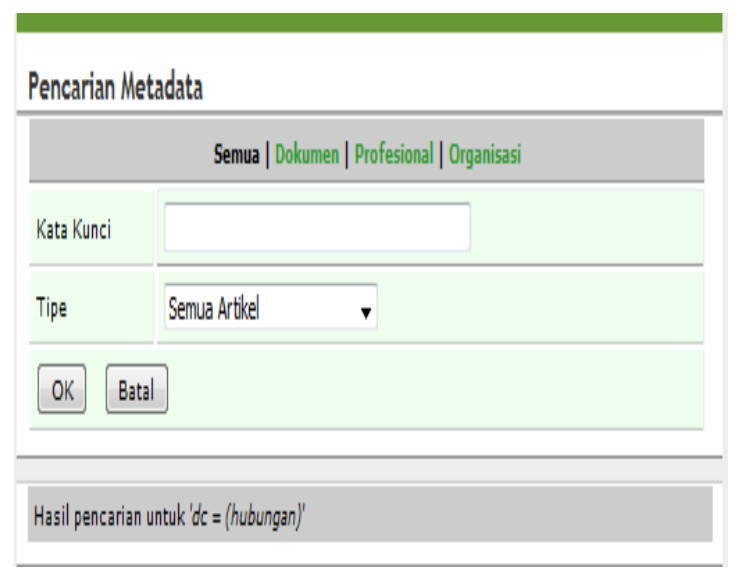

Gambar 3 Tampilan Saat User Melakukan Pencarian

\subsubsection{Desain}

Pada tahapan ini, fokus pada atribut program yang jelas seperti: software architecture, detail procedur (algorithm), data structure dan interface representations. Dalam Unified Modelling Language bentuk disain disajikan dalam berbagai diagram, antara lain:

a. Software Architecture: use case diagram perpustakaan online.

b. Detail procedure: sequency diagram, activity diagram, statemachin diagram.

c. Data Structure : class, class diagram
Tabel 9.Fungsi Utama Perangkat Lunak

\begin{tabular}{|c|c|c|}
\hline No & Nama fungsi & Deskripsi \\
\hline 1 & $\operatorname{login}$ & $\begin{array}{l}\text { Merupakan fungsi untuk } \\
\text { memverifikasi pengunjung dalam } \\
\text { mengoperasikan sistem. }\end{array}$ \\
\hline 2 & $\begin{array}{l}\text { mencari } \\
\text { koleksi }\end{array}$ & $\begin{array}{l}\text { Mencari koleksi baik dalam } \\
\text { bentuk digital maupun non digital } \\
\text { dengan memasukan satu kata } \\
\text { kunci atau beberapa kata kunci. }\end{array}$ \\
\hline 3 & $\begin{array}{l}\text { men- } \\
\text { download }\end{array}$ & $\begin{array}{l}\text { Merupakan fungsi untuk } \\
\text { mendownload digital resource. }\end{array}$ \\
\hline
\end{tabular}

Tabel 10. Fungsi Utama Perangkat Lunak Anggota

\begin{tabular}{ccl}
\hline No & Nama fungsi & \multicolumn{2}{c}{ Deskripsi } \\
\hline 1 & login & $\begin{array}{l}\text { Merupakan fungsi untuk } \\
\text { memverifikasi pengunjung dalam } \\
\text { mengoperasikan sistem. }\end{array}$ \\
& mencari & $\begin{array}{l}\text { Mencari koleksi baik dalam } \\
\text { bentuk digital maupun non digital } \\
\text { dengan memasukan satu kata } \\
\text { koleksi }\end{array}$ \\
& men- & $\begin{array}{l}\text { Merupakan atau beberapa kata kunci. } \\
\text { mendownload digital resource. }\end{array}$ \\
& download &
\end{tabular}

Tabel 11 Fungsi Utama Perangkat Lunak Pustakawan

\begin{tabular}{|c|c|c|}
\hline No & Nama fungsi & Deskripsi \\
\hline 1 & login & $\begin{array}{l}\text { Merupakan fungsi untuk } \\
\text { memverifikasi } \quad \text { pengunjung } \\
\text { dalam mengoperasikan sistem. }\end{array}$ \\
\hline 2 & $\begin{array}{c}\text { mencari } \\
\text { koleksi }\end{array}$ & $\begin{array}{l}\text { Mencari koleksi baik dalam } \\
\text { bentuk digital maupun non } \\
\text { digital dengan memasukan satu } \\
\text { kata kunci atau beberapa kata } \\
\text { kunci. }\end{array}$ \\
\hline 3 & $\begin{array}{c}\text { men- } \\
\text { download }\end{array}$ & $\begin{array}{l}\text { Merupakan fungsi untuk } \\
\text { mendownload digital resource. }\end{array}$ \\
\hline 4 & $\begin{array}{c}\text { mengelola } \\
\text { sirkulasi }\end{array}$ & $\begin{array}{l}\text { Merupakan fungsi untuk } \\
\text { membantu aktifitas pustakawan } \\
\text { untuk mengelola sistem. }\end{array}$ \\
\hline 5 & $\begin{array}{c}\text { menambah } \\
\text { anggota }\end{array}$ & $\begin{array}{l}\text { Merupakan fungsi untuk } \\
\text { menanbah, memperbaiki, dan } \\
\text { menghapus data anggota } \\
\text { perpustakaan. }\end{array}$ \\
\hline
\end{tabular}

Tabel 12. Fungsi Utama Perangkat Lunak SysAdmin

\begin{tabular}{|c|c|c|}
\hline No & Nama fungsi & Deskripsi \\
\hline 1 & $\log$ in & $\begin{array}{l}\text { Merupakan fungsi untuk } \\
\text { memverifikasi pengunjung dalam } \\
\text { mengoperasikan sistem. }\end{array}$ \\
\hline 2 & $\begin{array}{l}\text { menambah } \\
\text { pustakawan }\end{array}$ & $\begin{array}{lcr}\text { Merupakan } & \text { fungsi untuk } \\
\text { menambah, } & \text { memperbaiki, dan } \\
\text { menghapus } & \text { data anggota }\end{array}$ \\
\hline
\end{tabular}




\begin{tabular}{ccl} 
perpustakaan. \\
3 & $\begin{array}{c}\text { mengelola } \\
\text { migrasi }\end{array}$ & $\begin{array}{l}\text { Membuka hasil upload data dari } \\
\text { pustakawa untuk kemudian } \\
\text { dikonversi ke format yang sesui } \\
\text { dengan sistem. }\end{array}$ \\
\hline No & Nama fungsi & \multicolumn{1}{c}{ Deskripsi } \\
\hline 1 & Sysadmin & $\begin{array}{l}\text { Menguasai sistem secara } \\
\text { keseluruhan } \\
\text { Pengguna selain anggota perpus } \\
\text { Pengguna yang menjadi anggota } \\
\text { perpustakaan. } \\
\text { Petugas yang menangani } \\
\text { pengelolaan administrasi pada } \\
\text { perpustakaan. }\end{array}$ \\
\hline 4 & Pengunjung & Pnggota \\
\hline
\end{tabular}

\subsubsection{Use Case Diagram}

Use case pada dasarnya merupakan unit fungsionalitas koheren yang diekspresikan sebagai transaksi-transaksi yang terjadi antar actor dan sistem. [13] Use case diagram sistem baru dibuat mengacu pada use case diagram masing - masing sistem, yaitu use case diagram digital library. Use Case Diagram tersebut menjelaskan apa yang akan dilakukan oleh sistem digital library Universitas Bina Darma Palembang dan siapa yang berinteraksi dengan sistem.

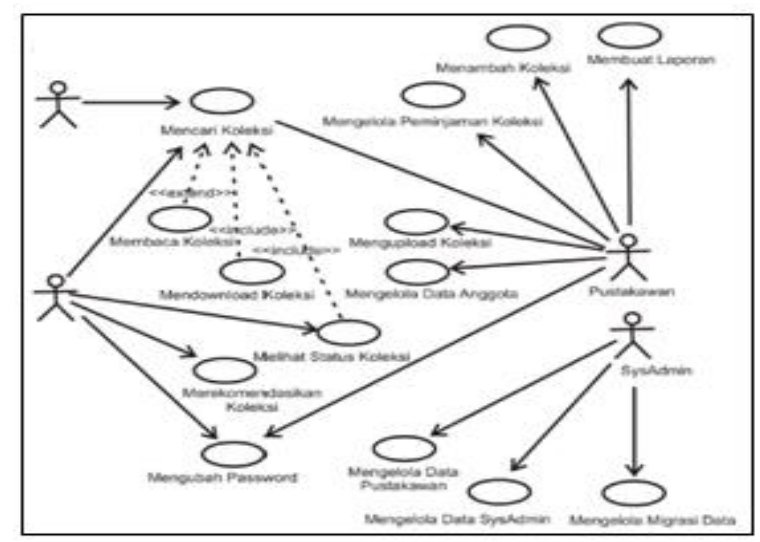

Gambar 4 Use Case Diagram integrasi Digital

\subsubsection{Activity Diagram}

Activity diagrammerupakan bentuk khusus dari state machine yang bertujuan memodelkan komputasikomputasi dan aliran-aliran kerja yang terjadi dalam sistem/ perangkat lunak yang sedang dikembangkan. [4] Activity diagram juga dapat menggambarkan proses paralel yang mungkin terjadi pada beberapa eksekusi. Di bawah ini merupakan activity diagram pada level sistem secara menyeluruh.

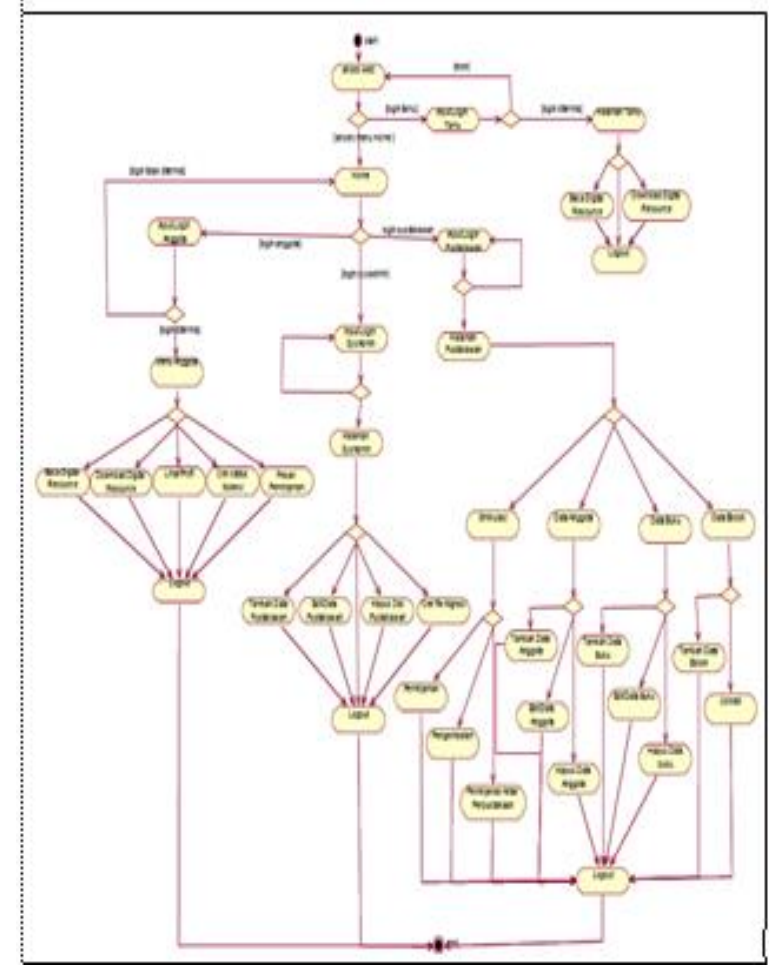

Gambar 5 Activity Diagram Sistem Menyeluruh

Gambar 5 merupakan alur kerja sistem digital library terhadap user secara menyeluruh. di bawah ini memperjelas lagi pada bagian activity mencari koleksi.

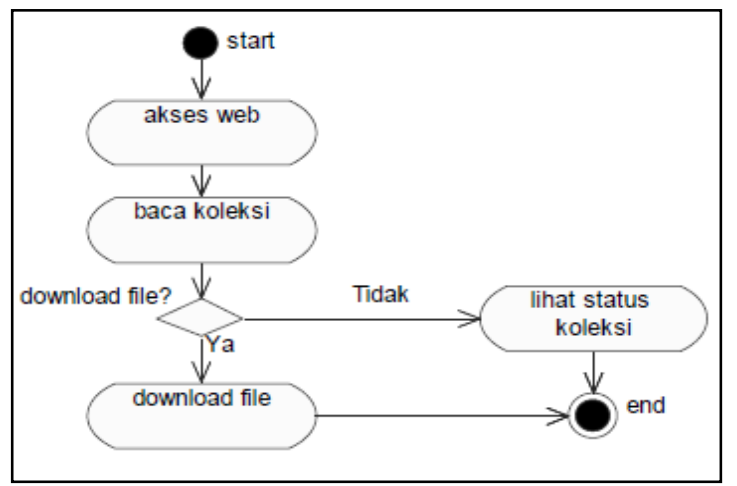

Gambar 6 Activity Mencari Koleksi

Gambar 6 menunjukkan bahwa activity mencari koleksi dimulai dari user membuka web, kemudian user membaca koleksi pilihan setelah membaca adalah mendownloadfile jika tersedia, atau melihat status koleksi.

\subsubsection{Desain Layout}

Desain Layout berfungsi sebagai dasar pembuatan interface dalam setiap halaman web yang akan dibuat. Berikut adalah desain layout untuk sistem yang akan di implementasikan. 


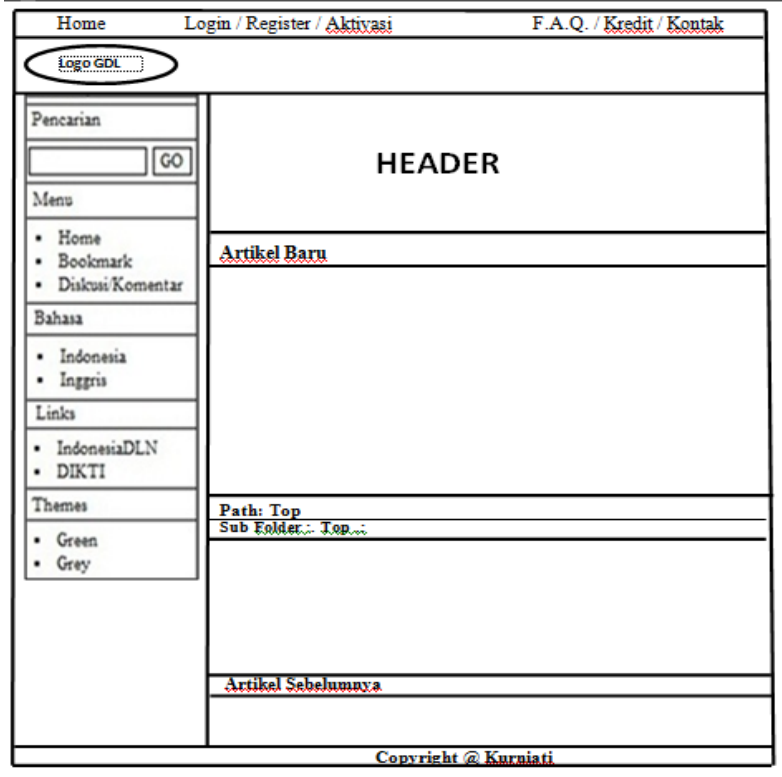

Gambar 7 Desain Lay out Halaman Utama

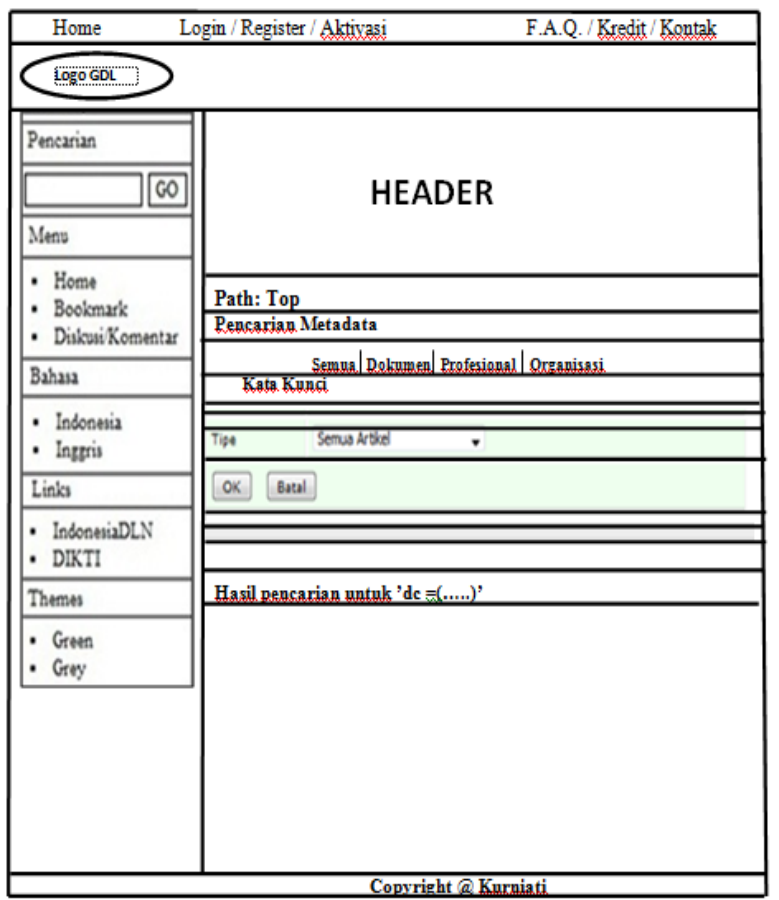

Gambar 8 Tampilan Menu Pencarian Yang Telah Dikembangkan

\subsubsection{Code}

Tahap code adalah tahapan dimana desain yang pers dihasilkan diterjemahkan dengan bahasa pemrograman dari data responden secara keseluruhan yang berjumlah menjadi bentuk fisik form maupun tabel, fungsi dan sebanyak seratus dua puluh orang responden, task yang prosedur. Pada pengembangan sistem digital library tidak berhasil ditemukan dapat dilihat pada aspek ini, digunakan aplikasi digital library yang bersifat learnability diperoleh persentase sebesar 96,2\%, aspek open sources yaitu GDL42 yang mana menggunakan efficiency diperoleh persentase sebesar 96,2\%, aspek bahasa pemrograman PHP versi lama dan database memorability diperoleh persentase sebesar 95,7\%, aspek error sebesar 94,8\%, dan pada aspek satisfactiondiperoleh persentase sebesar $95,7 \%$
MySQL sebagai penyimpan data. Sistem dijalankan pada localhost sebelum diupload pada web hosting.

\subsubsection{Evaluasi Berdasarkan Usability Testing}

Dalam penelitian usability testing yang diterapkan pada situs digital library Universitas Bina Darma ini, kukan pada lima orang sampel dari seratus dua tersebut. Hal ini dilakukan untuk mencapai tujuan dalam pengembangan sistem agar jauh lebih baik dari pada sebelumnya. Sehingga, pengguna akan dapat lebih merasakan manfaat dari penerapan digital library ni. Dari beberapa daftar pertanyaan atau task kuesioner diberikan kepada kelima responden yang sampel, maka akan diperoleh dua kategor task, yaitu: berhasil ditemukan dan tidak berhasil (temukan. penerapan digital library Universitas Bina Darma, dapat dilihat pada aspek learnability diperoleh persentase sebesar $0 \%$, aspek efficiency diperoleh persentase sebesar $0 \%$, aspek memorability diperoleh persentase sebesar 0\%, aspek error sebesar 4\%, dan pada aspek satisfaction diperoleh persentase sebesar sedangkan, jumlah total kelima aspek tersebut sebesar $0,8 \%$. Persentase angka terseb dibagi jumlah aspek. Namun, dari data responden secara keseluruhan yang berjumlah sebanyak seratus dua puluh orang responden, task yang berhasil ditemukan dapat dilihat pada aspek learnability diperoleh persentase sebesar 3,8\%, aspek efficiency eroleh persentase sebesar $3,8 \%$, aspek memorability persentase sebesar 4,3\%, aspek error sebesar $4,3 \%$ sedangkan, jumlah total kelima aspek tersebut adalah sebesar $0,2 \%$.

Sedangkan,dari task yang tidak bisa ditemukan jawabannya oleh responden dapat dilihat pada aspek learnability diperoleh persentase sebesar 100\%, aspek eficiency diperoleh persentase sebesar $100 \%$, aspek aspek error sebesar 94\%, dan pada aspek satisfaction diperoleh persentase sebesar $100 \%$ sedangkan, jumlah total kelima aspek tersebut adalah sebesar 99,2\%. Persentase angka tersebut diperoleh dari total jumlah persentasi kelima aspek dibagi jumlah aspek. Namun, 
sedangkan, jumlah total kelima aspek tersebut adalah sebesar $95,72 \%$.

\subsubsection{Reporting The Results And Making Recommendations To Improve The Design And Effectiveness Of The Product}

Dalam penerapan sistem digital library yang baik, sangatlah diperlukan feed back antara pengguna sistem dan admin yang aktif. Berdasarkan hasil usabilitytest yang telah dilakukan pada kelima responden yang terpilih dilihat dari lima aspek usability, maka didapat masukan seperti di bawah ini:

\subsubsection{Learnability}

Dari lima orang sampel responden menunjukan bahwa sistem digital library pada aspek learnability sudah baik. Menu yang ada pada menu utama digital library Universitas Bina Darma seperti pada gambar 14 sudah berjalan dengan baik. Namun, pada menu pencarian masih membutuhkan peningkatan karena saat user melakukan pencarian informasi, informasi tidak ditemukan karena terdapat masalah pada metadatanya.

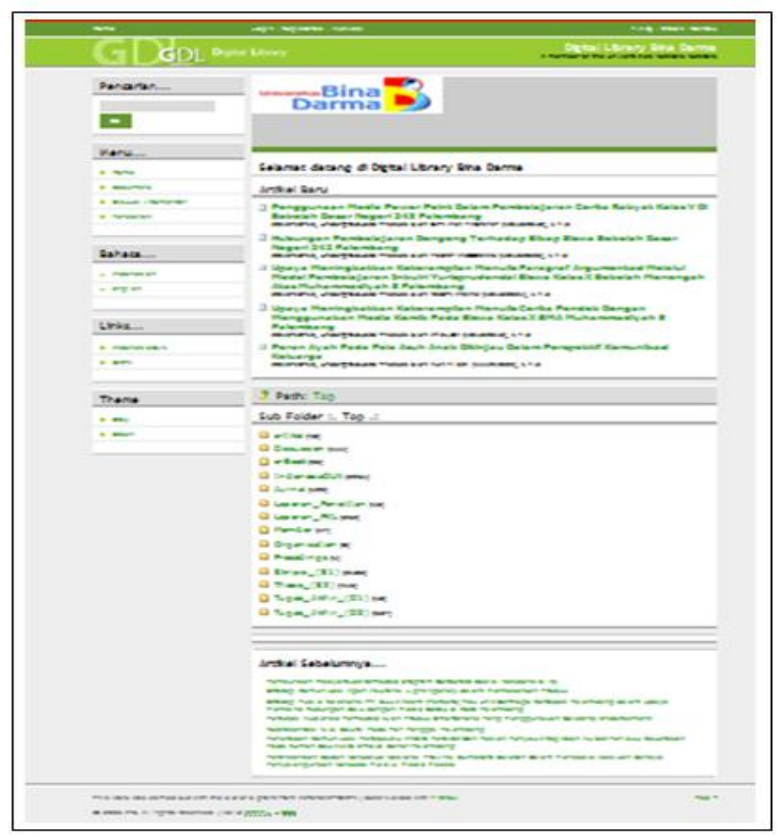

Gambar 9 Tampilan Home Digilib

\subsubsection{Efficiency}

Dari lima orang sampel responden menunjukan bahwa sistem digital library pada aspek efficiency sudah cukup baik. Saat user melakukan pencarian alamat digital library Universitas Bina Darma, user dapat dengan mudah dan cepat menemukan alamat tersebut. Selain itu, dengan adanya sistem ini cukup membantu dalam memperoleh referensi bagi user untuk kebutuhan penelitian.

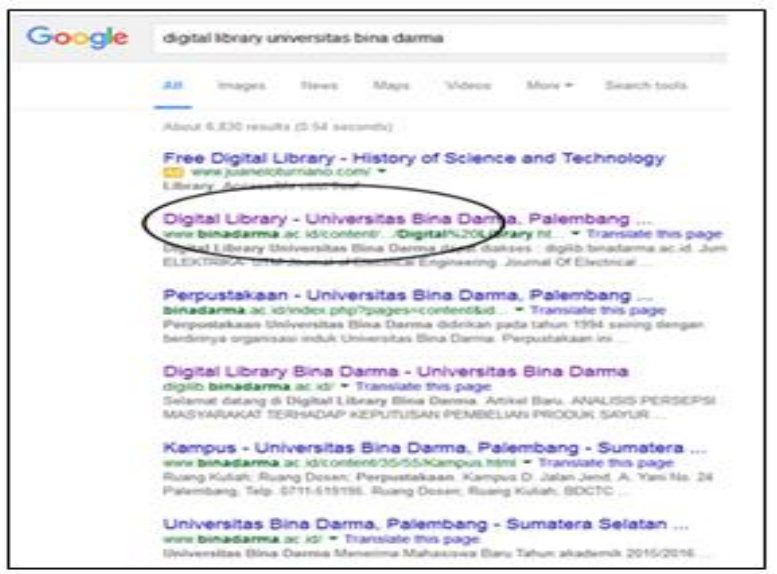

Gambar 10 Tampilan Pencarian di Google.co.id

\subsubsection{Memorability}

Dari lima orang sampel responden menunjukan bahwa sistem digital library pada aspek memorability sudah baik. Dilihat dari menu yang ada pada sistem juga mudah diingat dan dipahami. Akan tetapi, masih kurangnya sosialisasi akan adanya penerapan sistem ini di lingkungan Universitas Bina Darma. Sehingga, tidak banyak yang mengetahui akan adanya sistem digital library tersebut. Padahal sistem ini sudah lama diterapkan dan semestinya semua civitas akademika Universitas Bina Darma sudah sejak lama bisa merasakan manfaat dari sistem tersebut. Sistem ini sangat membantu dalam pencarian referensi penelitian dengan mudah tanpa harus datang ke Perpustakaan Universitas Bina Darma karena mudah diakses di mana saja.

\subsubsection{Error}

Dari lima orang sampel responden menunjukan bahwa sistem digital library pada aspek error kurang baik. Terutama pada menu pencarian tidak berfungsi, user dalammencari informasi masih harus mencari secara manual. Sehingga, user mengalami kesulitan karena kurang efektif dan membutuhkan waktu yang lama. Hal ini di dapat dilihat pada gambar $11-13$.

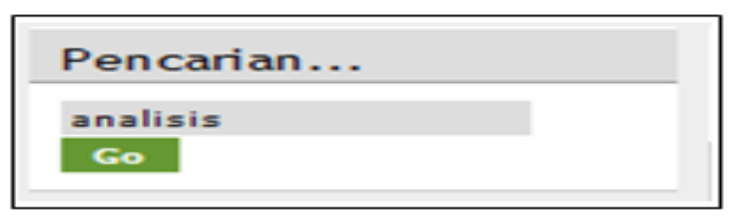

Gambar 11 Tampilan Menu Pencarian 


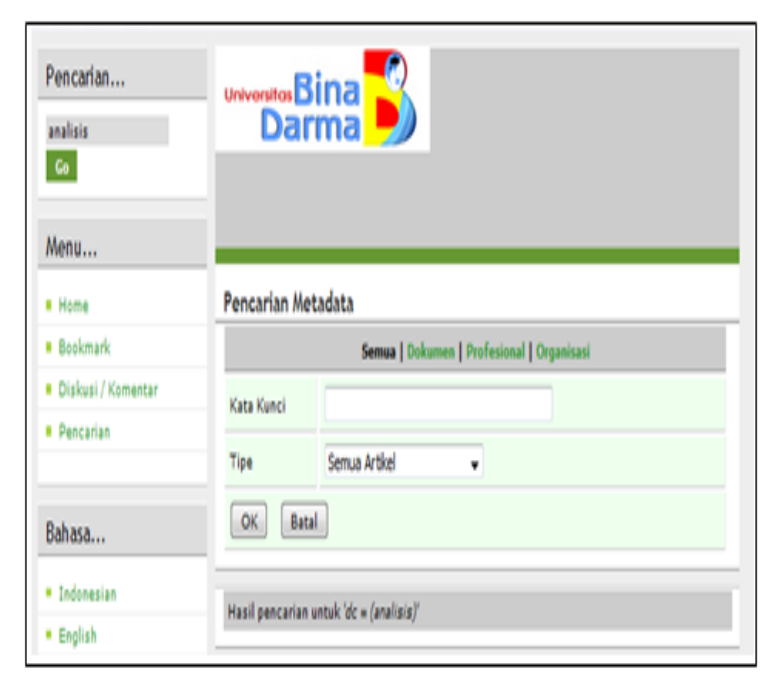

Gambar 12. Tampilan Saat User Melakukan Pencarian

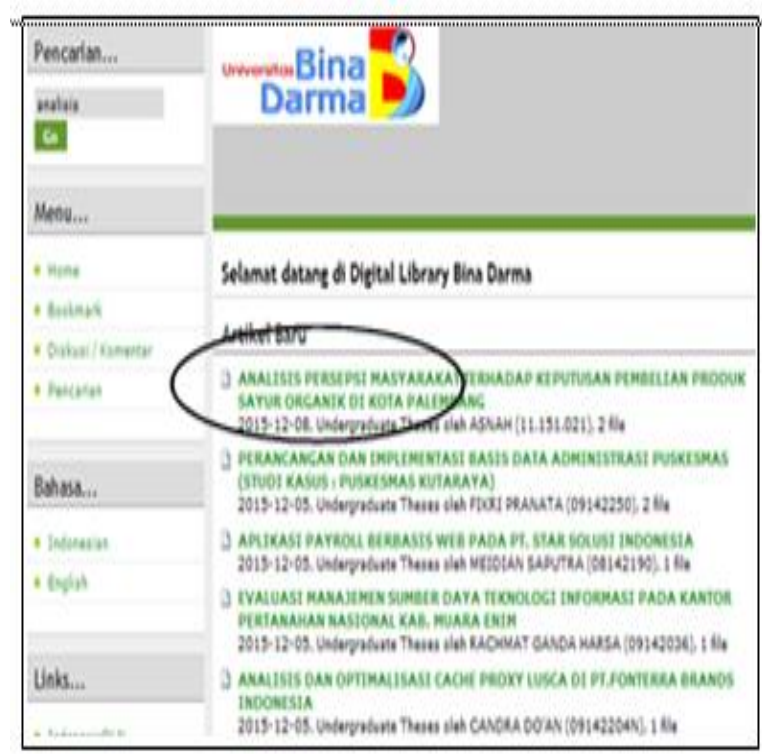

Gambar 13. Tampilan Menu Utama

Dari ketiga gambar di atas menunjukan bahwa pada saat user mencari informasi dengan mengetikkan kata “ Analisis “, user tidak memperoleh informasi tersebut dan yang ditampilkan sistem adalah ke menu pencarian metadata. Padahal, informasi yang berhubungan dengan kata "Analisis" ini ada seperti ditunjukan pada gambar 18 di atas.

\subsubsection{Satisfaction} Dari lima orang sampel responden menunjukan bahwa terhadap metadata tidak berfungsi dan harus dijalankan sistem digital library pada aspek satisfaction secara secara manual.

keseluruhan sudah sesuai dengan yang dibutuhkan pengguna, dilihat dari data yang ditunjukan pada tabel 4.44 sebesar 68\%. Namun, user masih mengalami Berdasarkan hasil penelitian di atas, salah satu cara ketidakpuasan saat mencari informasi yang mereka untuk memaksimalkan dan meningkatkan minat civitas butuhkan dikarekan, menu pencarian pada digital akademika Universitas Bina Darma terhadap library tidak berfungsi sebagaimana mestinya.
Seharusnya, dengan mengakases sistem ini akan mempermudah user dalam mendapatkan informasi tanpa harus melakukan pencarian secara manual dan datang langsung ke Perpustakaan Bina Darma. Untuk mengatasi masalah tersebut, dilakukan pengembangan pada menu pencarian agar dapat berfungsi efektif dan mempermudah user untuk memperoleh informasi. Perbaikan pada menu pencarian ini dapat dilihat pada gambar 14.

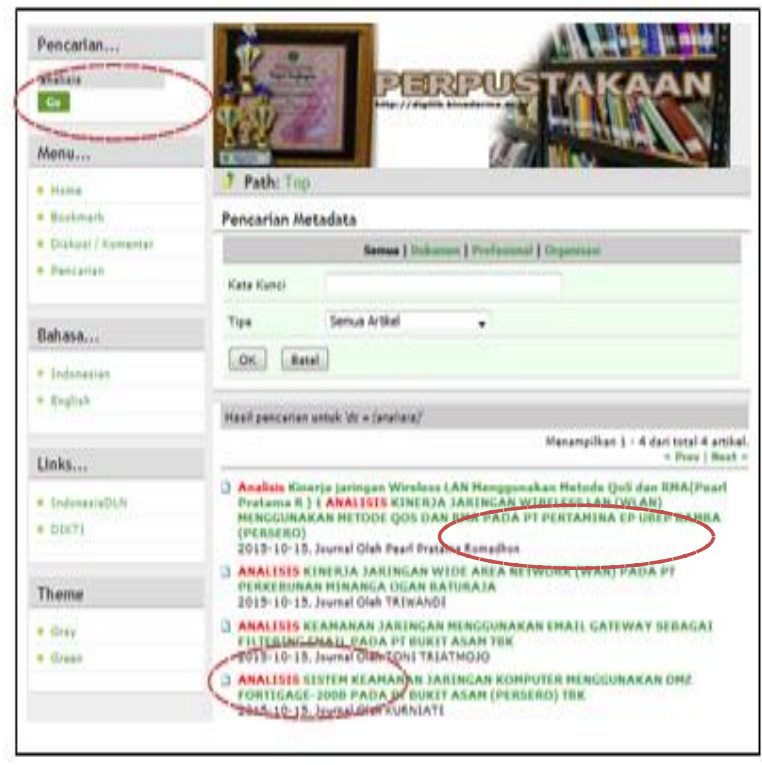

Gambar 14.Tampilan Menu Pencarian Yang Telah Dikembangkan

Dari gambar 14 terlihat bahwa saat user melakukan pencarian informasi maka menu pencarian metadata akan menampilkan hasil temuan. Ternyata alasan kenapa menu pencarian tidak berfungsi adalah admin tidak melakukan update index setelah melakukan update informasi atau setelah melakukan upload file yang baru.

\subsection{Rekomendasi}

Penerapan Digital Library Universitas Bina Darma Palembang secara keseluruhan sudah baik. Namun, untuk memaksimalkan fungsi dari sistem tersebut dilakukan pengembangan pada menu pencarian yang dinilai belum maksimal berdasarkan data yang didapat. Hal ini disebabkan kurangnya sosialisasi akan penerapan sistem tersebut dan juga tidak adanya hak akses untuk melakukan update index yang didapat oleh terhadap metadata tidak berfungsi dan harus dijalankan

4.6.1 Sosialisasi

penerapan digital library yaitu dengan cara melakukan 
sosialisasi. Dengan diadakannya sosialisasi, diharapkan Tampilan home digilib seperti yang ditunjukan pada digital library ini akan lebih dikenal dan dapat gambar 16, tidak melakukan perubahan secara dirasakan manfaatnya oleh semua civitas akademika signifikan pada desain interface home digilib. Desain dalam mencari informasi guna menyelesaikan interface digilib UBD sudah dinilai baik. Oleh karena penelitian mereka. Di bawah ini adalah gambaran saat itu, hanya melakukan perubahan pada tampilan dilakukannya sosialisasi:

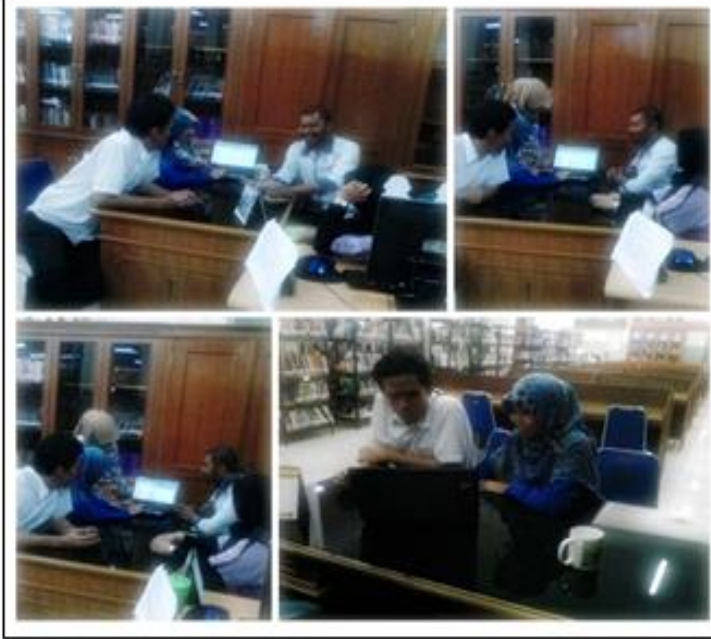

Gambar 15 Pelaksanaan Sosialisasi Sistem

\subsubsection{Pengembangan Menu Pencarian Metadata}

Berdasarkan hasil penelitian di atas, selain kurang Untuk tampilan menu pencarian metadata sama seperti adanya sosialisasi yang menjadi masalah utama adalah tampilan home new digilib secara fisik tidak mengalami menu pencarian metadata yang tidak berfungsi maksimal. Oleh karena itu, dilakukan pengembangan guna meningkatkan fungsi menu tersebut dengan cara melakukan percobaan menggunakan aplikasi opensources yaitu GDL42. Di bawah ini merupakan hasil pengembangan sistem yang dilakukan yang hanya fokus pada pengembangan menu pencarian metadata, seperti gambar 16.

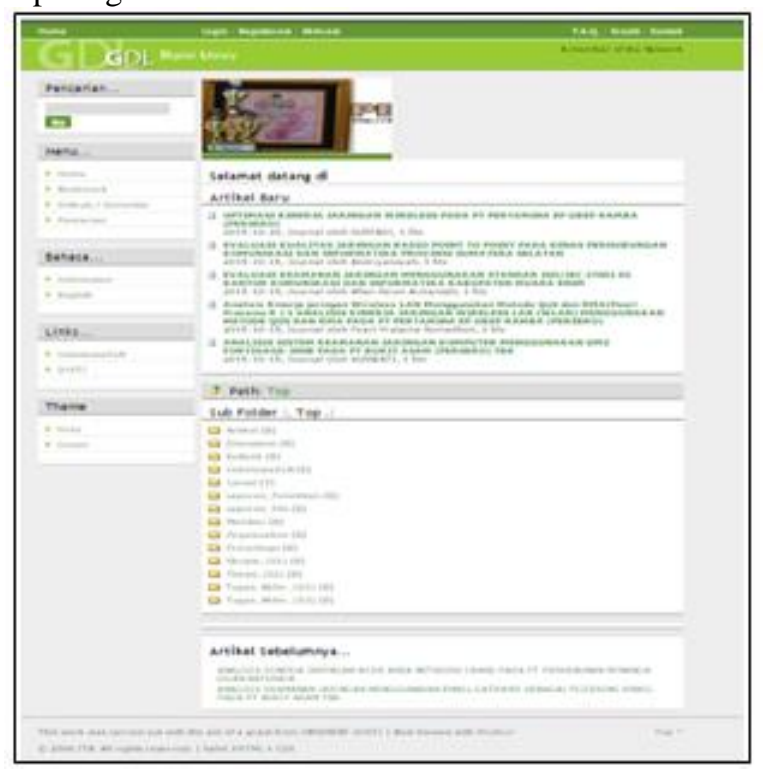

Gambar 16. Tampilan Home New Digilib headernya saja.

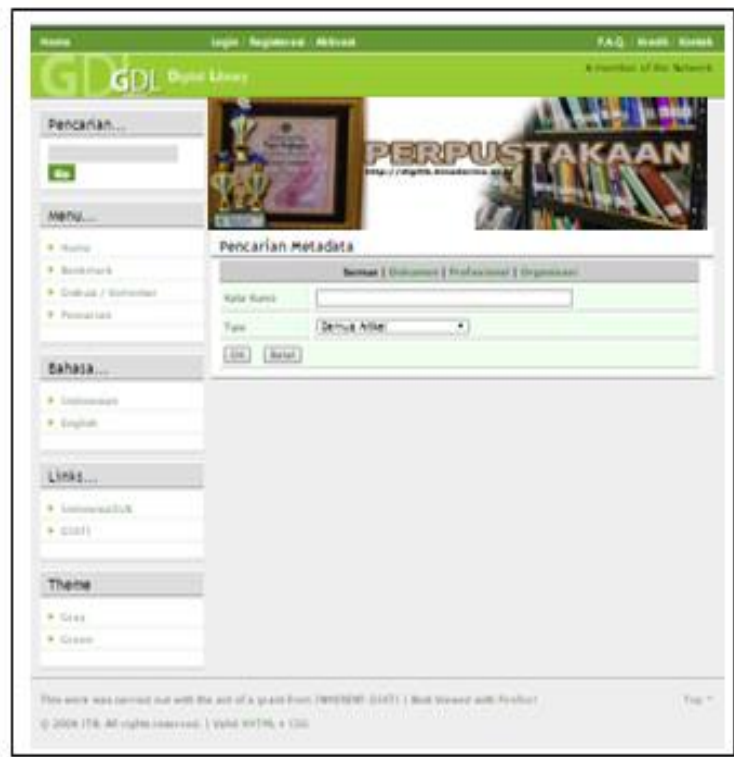

Gambar17. Tampilan Menu Pencarian Metadata informasi contohnya jurnal, user cukup mengetikan metadata yang akan dicari, maka pada tampilan menu pencarian metadata akan menampilkan semua yang berkaitan dengan metadata tersebut. Sehingga, menu pencarian akan berfungsi sebagaimana mestinya, user tidak perlu mencari informasi secara manual serta penerapan digital library UBD akan lebih efektif dan efisien. Hal ini dapat dapat dilihat pada gambar 18.

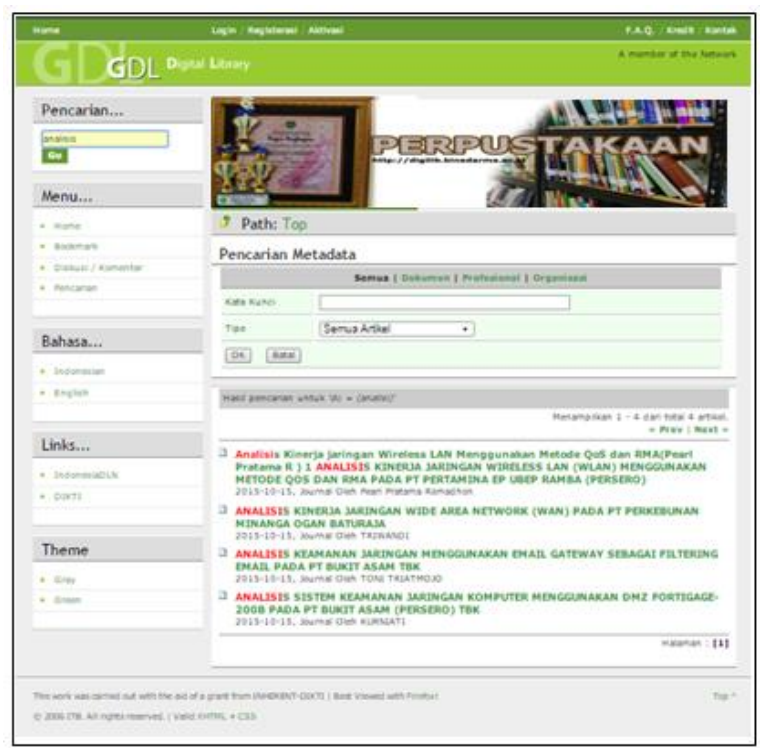

Gambar 18.Tampilan Hasil Pencarian Metadata 
Pada bagian berisi penjelasan ilmiah dari hasil penerapan metode penelitian yang telah ditetapkan pada sub metode penelitian.

\section{Kesimpulan}

Simpulan dan saran atas penelitian hasil penelitian.

\subsection{Simpulan}

Simpulan yang dapat diambil diantaranya:

1. Aspek learnability sudah baik berdasarkan respon user. Hal inimenunjukan kesesuian dalam sistem tersebut.

2. Aspek effeciency cukup baik ditunjukan oleh saat user melakukan pencarian alamat digital library Universitas Bina Darma, user dapat dengan mudah dan cepat menemukan alamat tersebut..

3. Aspek memoribility sudah baik, dilihat dari menu yang ada pada sistem mudah diingat dan dipahami. Namun, masih kurangnya sosialisasi terhadap sistem di lingkungan Universitas Bina Darma mengakibatkan tidak banyak orang yang mengetahui akan adanya sistem digital library tersebut.

4. Aspek error kurang baik, karena pada saat pengujian terhadap kinerja digital library ternyata menu pencarian masih tidak berfungsi. Hal ini ditunjukan oleh, saat user mencari informasi masih harus mencari secara manual.

5. Aspek satisfaction sudah baik dan pengguna sudah cukup puas. Namun, dikarenakan sistem pencarian yang tidak berfungsi, user merasa kesulitan dalam mencari informasi, dan tidak update nya informasi yangada pada digital library Universitas Bina Darma.

6. Digital library Universitas Bina Darma secara keseluruhan sudah baik, terutama desain interface sistemnya sudah user friendly. Oleh sebab itu, hanya memaksimalkan fungsi dari pencarian metadata yang merupakan masalah utama dalam penelitian ini. Tidak berfungsinya menu pencarian metadata dikarenakan tidak adanya hak akses yang diperoleh admin perpustakaan untuk melakukan update index setelah melakukan update data pada sistem. Sehingga, dengan dimaksimalkannya fungsi dari menu tersebut maka, user akan lebih mudah dan cepat dalam melakukan pencarian data.

\subsection{Saran}

Saran yang dapat diambil diantaranya:

1. Terhadappenerapan digital library Universitas Bina Darma ini, civitas akademika masih belum banyak yang mengetahui akan keberadaan sistem tersebut. Oleh sebab itu, diharapkan adanya sosialisasi untuk memperjelas manfaat apa yang akan didapat jika user mengakses sistem tersebut.

2. Dalam pengelolaan sistem ini diharapkan selalu melakukan update saat admin melakukan perbaharuan informasi dengan melakukan update index.

\section{Ucapan Terima Kasih}

Dengan selesainya jurnal penelitian ini diucapkan terima kasih kepada civitas Universitas Bina Darma Palembang.

\section{Daftar Rujukan}

[1] Santoso, Hisap. 2009.Interaksi Manusia dan Komputer edisi 2. Yogyakarta: Andi Offset .

[2] Prihati, Dkk. 2014.Penerapan model human computer interaction (hci) dalam analisis sistem informasi. Jurnal Magister Sistem Informatika.Universitas Diponegoro : Semarang.

[3] Darmono.2007.Perpustakaan Digital: Pendekatan Aspek Manajemen dan Tata Kerja.. Jakarta: Grasindo.

[4] Sulianta, Feri. 2010. IT Ergonomics. Jakarta: PT. Alex Media Komputindo.

[5] Sugiyono. 2012. Metode Penelitian Kuantitatif dan Kualitatif dan $R \& D$. Alfabeta : Bandung.

[6] Saepul dan Bahruddin. 2014. Metode Penelitian Kuantitatif Aplikasi dalam pendidikan. Yogyakarta: Deepublish.

[7] Siyoto dan Ali. 2015. Dasar Metodologi penelitian. Yogyakarta: Literasi Media Publishing.

[8] Soekarno, Muhammad, Putra. 2018.Faktor-Faktor Pengembangan Sistem Informasi Akademik Berbasis Web Pada Perguruan Tinggi Swasta Palembang.Jurnal Resti ( Rekayasa Sistem dan Teknologi Informasi) 2(1). pp.295-300.

[9] Al Fatta, Hanif. 2007. Analisis dan Perancangan Sistem Informasi untuk Keunggulan Bersaing Perusahaan dan Organisasi Modern. Yogyakarta: Andi Offset.

[9] Sigit,H.P. 2013.Analisis Usability Aplikasi Berbasis Web Dengan Mengadopsi Model Kepuasan Pengguna(User Satisfaction). Jurnal Sistem Informatika.Universitas Indonesia : Depok. 6(1). pp. 65-73.

[11] Sari, Febriana.2018. Metode Dalam Pengambilan Keputusan. Yogyakarta: DEEPUBLISH.

[12] Mulyani, Sri. 2016. Sistem Informasi Manajemen Rumah Sakit: Analisis dan Perancangan. Bandung: Abdi Sistematika.

[13] Nugroho, Adi. 2010. Rekayasa perangkat Lunak Berorientasi Objek dengan Metode USDP ( Unified Software Development Process). Yogyakarta: Andi Offset. 